\title{
THE ANALYSIS OF DIFFERENT TECHNIQUES FOR SPEED CONTROL OF PERMANENT MAGNET SYNCHRONOUS MOTOR
}

\author{
Mustafa Dursun, Ali Fuat Boz
}

Original scientific paper This paper presents the use of proportional integral (PI), proportional integral derivative (PID) and fuzzy logic (FL) speed controller techniques in the permanent magnet synchronous motor (PMSM) drive. PI and PID controllers require precise linear mathematical model of the system. On the other hand, FL needs linguistic description of the system. The dynamic response of PMSM with the controllers was studied under different load disturbances. The effectiveness of the fuzzy logic controller was compared with the conventional PI and PID controllers. The FL controller responded better than conventional techniques under transient load conditions and also achieved faster settling response.

Keywords: fuzzy logic controller; permanent magnet synchronous motor (PMSM); PI controller; transient loads

Analiza različitih tehnika reguliranja brzine sinkronog motora s permanentnim magnetima

Izvorni znanstveni članak

U radu se predstavljaju tehnike reguliranja brzine primjenom proporcionalnog integrala (PI), derivacije proporcionalnog integrala i fuzzy logike u pogonu sinkronog motora s permanentnim magnetima. PI i PID regulatori zahtijevaju precizni linearni matematički model sustava. S druge strane, FL zahtijeva lingvistički opis sustava. Analizirana je dinamička reakcija PMSMa na regulatore pri različitim opterećenjima. Uspoređena je učinkovitost reguliranja fuzzy logikom i uobičajenim načinima pomoću PI i PID. FL regulatori su reagirali bolje od uobičajenih tehnika pri prelaznim uvjetima opterećenja te postigli bržu regulaciju.

Ključne riječi: PI regulator; prelazna opterećenja; regulator neizrazite (fuzzy) logike; sinkroni motor s permanentnim magnetima

\section{Introduction}

Permanent Magnet Synchronous Motor (PMSM) has been widely used in high performance applications due to its advantages such as compactness, high efficiency, and reliability, high torque to current ratio and large power to weight ratio [1].

The controller design for PMSM model plays an important role in the system performance. Usually, the PI control is used in the speed loop of PMSM closed loop control system. Control algorithm of the conventional PI control strategy is easy to realize, so higher steady-state accuracy could be acquired and it could be widely used in engineering practice. On the other hand, the adverse nonlinear nature of PMSM interior variables, the coupling characteristics and the external disturbances make it difficult to build the accurate mathematical model of controlled object and the controlled object often changes with the working condition. The expected control performance index could only be acquired through precise mathematical model and dynamic response of the system. Again, anti-disturbance performance of the system is not ideal enough [2]. Therefore, a suitable control method is necessary in order to obtain good adjustment performances in various working conditions. But, it is very difficult to identify system characteristics and dynamic control parameters in real time due to the complexity of PMSM servo system. Therefore, many nonlinear control methods have been developed to improve the system control performances for different disturbances and uncertainties, for example, examined dynamic behaviour model of permanent magnet synchronous motor using PWM inverter and fuzzy logic controller for stator phase current, flux and torque control of PMSM [3]. Examined current, voltage, speed and torque variation graphs and realized performance analysis with FL controller of PMSM driver [4]. Simulation results are compared with responses obtained from experiments and FL fundamental speed control of Interior PMSM is made [5]. Measurement of real parameters for high speed PMSMs is carried out and comparison is made between calculated values and measured values [6]. Additionally, some techniques were proposed in literature such as robust control $[7,8]$, sliding mode control (SMC) $[9,10$, $11,12]$, adaptive control [13], back stepping control [14], predictive control [15], intelligent control [16, 17] and so on. All these control methods have been designed to improve the performance of PMSM at the various speeds and load conditions.

This paper presents the PI, PID and FL speed controllers for the PMSM system. The controllers were designed to achieve zero steady state error, minimum overshoot and minimum settling time. At the same time, these methods can guarantee both robust control and closed-loop stability of the PMSM drive systems over the existing control strategies. To verify the methods, a simulation system was implemented in the MATLAB environment. The dynamic performance of the system was studied under the load changes and parameter variations of the PMSM drive system. The simulation results were provided to demonstrate the effectiveness of the FL method.

\section{Permanent Magnet Synchronous Motor (PMSM) modelling}

Mathematical model of the PMSM system can be expressed by such equations in the rotating reference frame $(d-q$ reference frame). Accordingly, the rotor reference plane of the PMSM equivalent circuit can be shown as in Fig. 1 [18]. 


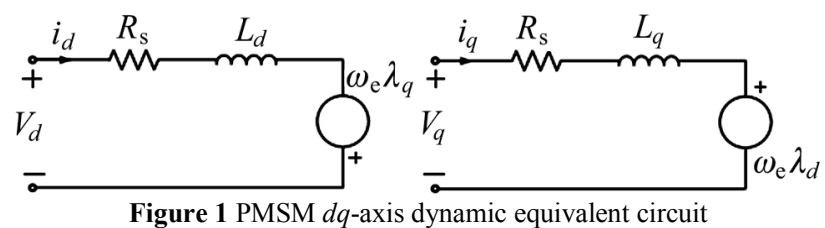

Stator $d q$ equations can be written in the rotor reference plane of PMSM using Fig. 1 as:

$V_{d}=R_{\mathrm{s}} \cdot i_{d}+L_{d} \frac{\mathrm{d} i_{d}}{\mathrm{~d} t}-\omega_{\mathrm{e}} \lambda_{q}$

and

$V_{q}=R_{\mathrm{s}} \cdot i_{q}+L_{q} \frac{\mathrm{d} i_{q}}{\mathrm{~d} t}+\omega_{\mathrm{e}} \lambda_{d}$

where $V_{d}$ and $V_{q}$ are dq-axis voltages, $i_{d}$ and $i_{q}$ are dq axis currents, $\lambda_{d}$ and $\lambda_{q}$ are $d q$-axis fluxes and $\omega_{\mathrm{e}}$ is the electrical rotor speed. The fluxes are described in Eqs. (3) and (4) [18].

$\lambda_{d}=L_{d} \cdot i_{d}+\lambda_{\mathrm{m}}$

$\lambda_{q}=L_{q} \cdot i_{q}$.

The expression of $\lambda_{\mathrm{m}}$ represents mutual magnetic flux caused by the permanent magnet. Expression of the induced torque is provided with Eq. (5) [18].

$T_{\mathrm{e}}=\frac{3}{2} P\left(\lambda_{\mathrm{m}} \cdot i_{q}\right)+\left(L_{d}-L_{q}\right)\left(i_{d} \cdot i_{q}\right)$

For constant flux operation, the electromagnetic torque is

$T_{\mathrm{e}}=\frac{3}{2} P\left(\lambda_{\mathrm{m}} \cdot i_{q}\right)$
$P$ is the number of pairs of poles. The first term in the expression is the torque produced by the magnet and the second term is the reluctance torque due to the difference in reluctances. Because $d q$-axis inductances in PMSM are equal to each other, the reluctance torque will be zero. The mechanical expression is provided in Eq. (7) [18].

$T_{\mathrm{m}}=T_{\mathrm{L}}+B \cdot \omega_{\mathrm{r}}+J \cdot \frac{\mathrm{d} \omega_{\mathrm{r}}}{\mathrm{d} t}$

where $\omega_{\mathrm{r}}$ is the mechanical speed, $J$ is the inertia moment of the motor and $T_{\mathrm{L}}$ is the load torque. $\omega_{\mathrm{r}}$ is expressed as follows.

$\omega_{\mathrm{r}}=\int\left(\frac{T_{\mathrm{m}}-T_{\mathrm{L}}-B \cdot \omega_{\mathrm{r}}}{J}\right) \cdot \mathrm{d} t$.

The torque equation for PMSM resembles to that of the regular DC motor. Therefore, it may facilitate the control of the machine very efficiently. The motor currents are decomposed into id and $i_{q}$ components in the rotor based dq coordinates system. The maximum torque is obtained with $i_{d}=0$ which corresponds to the case when the rotor and stator fluxes are perpendicular. The operation of the drive is then similar to that of armature current controlled DC motor. The drive behaviour can be adequately described by a simplified model expressed by the Eq. (7) [19].

\section{Control structure}

Fig. 2 illustrates the block diagram of the Field Oriented Control (FOC) scheme based PMSM drive system used in this work. The rotor speed $\omega_{\mathrm{r}}$, was compared with the reference speed $\omega_{\text {ref. }}$. The resulting error was processed in the PI, PID or FL speed controllers for each sampling interval. The output of the controller was then considered to be the reference torque $T_{\mathrm{em}}^{*}$.

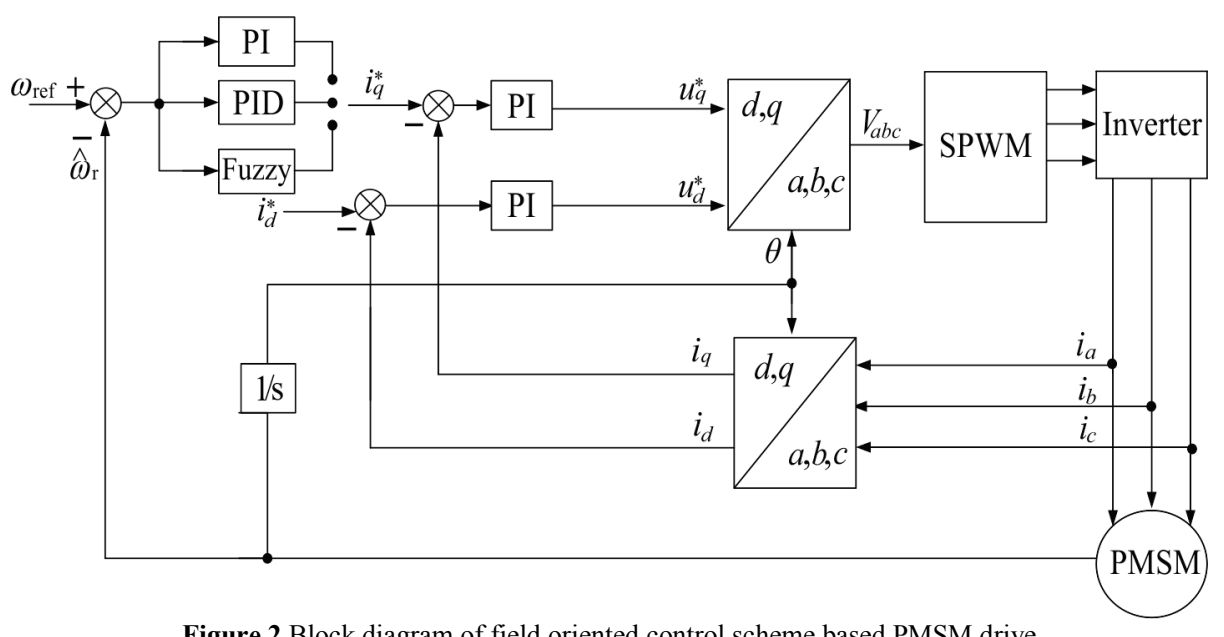

Figure 2 Block diagram of field oriented control scheme based PMSM drive

\section{$4 \quad \mathrm{PI}$ and PID controllers}

A proportional-integral-derivative controller (PID controller) is a feedback control loop mechanism which is widely used in control systems in industries. A PID controller calculates the difference between a measured process variable and a desired set-point which is considered as an error. By manipulating the variables the error can be reduced by the controller. 
The controller can provide control action designed for specific process required by tuning the three parameters in the PID controller. Some of the applications may require using only one or two actions to provide the appropriate system control. This is achieved by keeping the other parameters to zero. A PID controller will be called PI, PD, P or I controller in the absence of the respective control actions. PI controllers are quite common, since the derivative action is sensitive to measurement of noise, whereas the absence of an integral term may prevent the system from reaching its desired value due to the control action [21].

The principle of a conventional PID controller is shown in Fig. 3.

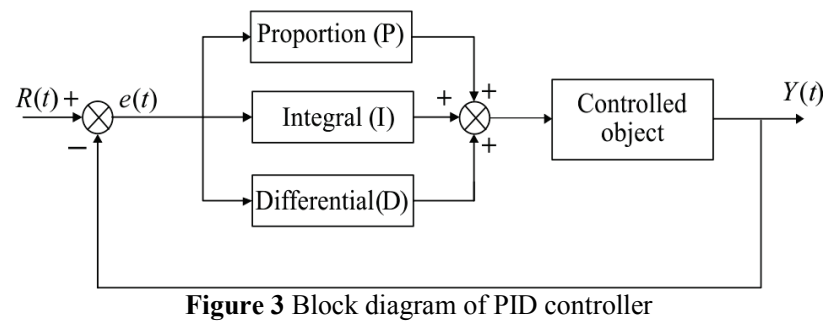

The error $e(t)$, which exists between the given value $R(t)$ and the actual output value $Y(t)$, is used by PID controller to constitute the control through the linear combination of proportion (P), integral (I) and differential (D) so as to achieve the effective control of the controlled object. The conventional PID control process is written in the form of transfer function as:

$G(s)=\frac{U(s)}{R(s)}=K_{\mathrm{p}}\left(1+\frac{1}{T_{\mathrm{i}} s}+T_{\mathrm{d}} \cdot s\right)=K_{\mathrm{p}}+K_{\mathrm{i}} \frac{1}{s}+K_{\mathrm{d}} \cdot s$.

In formula (9), $K_{\mathrm{p}}$ is the proportional action coefficient, $K_{\mathrm{i}}$ is the integral action coefficient and $K_{\mathrm{d}}$ is the differential action coefficient. Transfer function can be easily changed by adjusting the parameters $K_{\mathrm{p}}, K_{\mathrm{i}}$ and $K_{\mathrm{d}}$, for which the control effect of the PMSM vector control system can be greatly improved [22].

Usually, the conventional PI controller is preferred for speed control in outer loop due to its simplicity in implementation and satisfying performance during steady state. However, its response depends on the gain values of proportional $\left(K_{\mathrm{p}}\right)$ and integral $\left(K_{\mathrm{i}}\right)$ which are responsible for the sensitivity of error speed in steady state. Highly precise mathematical model of the system and appropriate gain values are required to achieve high performance drive. Fig. 4 shows the block diagram for a conventional PI controller.

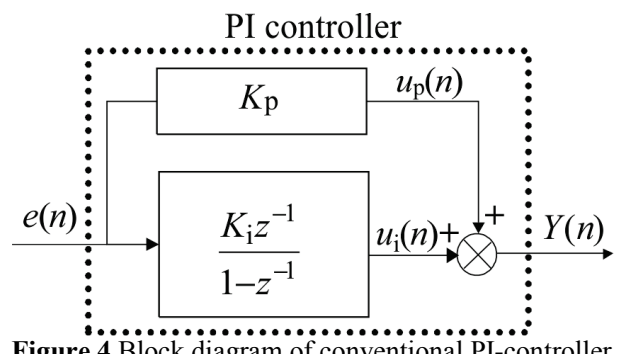

Figure 4 Block diagram of conventional PI-controller
In the PI-controller, they require high gain values for speeding up the motor and for quick load disturbances rejection. Therefore sudden change in load condition or speed change will result in overshoot, oscillation in speed, high torque ripple and high stator flux ripple.

$$
\begin{aligned}
U_{\mathrm{p}}(n) & =K_{\mathrm{p}} e(n), \\
U_{\mathrm{i}}(n) & =U_{\mathrm{i}}(n-1)+K_{\mathrm{i}} \cdot e(n-1), \\
Y_{n}(n) & =U_{\mathrm{p}}(n)+U_{\mathrm{i}}(n)= \\
& =U_{\mathrm{i}}(n-1)+K_{\mathrm{p}} \cdot e(\mathrm{n})+K_{\mathrm{i}} \cdot e(n-1) .
\end{aligned}
$$

where $K_{\mathrm{p}}$ is proportional coefficient, $K_{\mathrm{i}}$ is integral coefficient, $Y_{n}(n)$ is the output control volume in the nsampling time, $e(n)$ is the input deviation in the $\mathrm{n}$ sampling time, $e(n-1)$ is the input deviation in the $(n-$ 1)-sampling time [23].

\section{$5 \quad$ Fuzzy logic controller}

Various applications of the FL have shown fast growth in the past few years. Also, FLC has become popular in the field of industrial control applications for solving control, estimation and optimization problems [19]. In this section, a FL controller was proposed to replace the PI controller used for error minimization in the conventional PI speed controller.

If the structure of the FL controller, given in Fig. 5, is investigated, it can be seen that the controller has two input variables namely the speed error $e$ and the change of speed error $d_{e}$ [19]. At the same time, change in the reference phase current $i_{q}{ }^{*}$ was output $\Delta i_{q}{ }^{*} . e$ and $d_{e}$ were then calculated as in Eqs. (13) and (14) for every sampling time:

$$
\begin{aligned}
& e(k)=w^{*}(k)-w_{\mathrm{r}}(k), \\
& d_{e}(k)=e(k)-e(k-1) .
\end{aligned}
$$

The structure of the fuzzy logic system is given in Fig. 3.

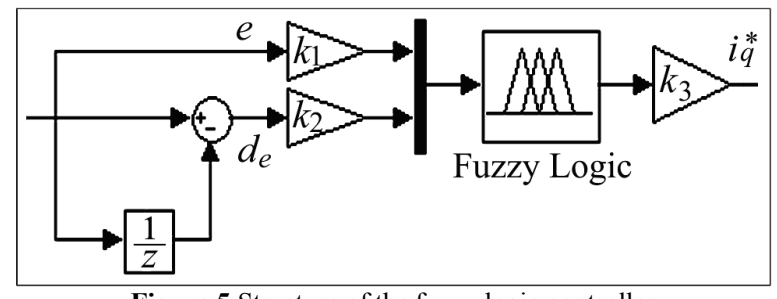

Figure 5 Structure of the fuzzy logic controller

These two inputs were multiplied by two scaling factors $k_{1}$ and $k_{2}$, respectively. The output of the controller was multiplied by a third scaling factor $k_{3}$.

The choice of the values of the scaling factors greatly affects the performance of the FLC. A trial and error technique is usually used to tune these gains to ensure optimal performance of the controllers [20]. Each variable of the FLC has seven membership functions. The following fuzzy sets were used: NB = negative big, $\mathrm{NM}=$ negative medium, $\mathrm{NS}=$ negative small, $\mathrm{ZE}=$ zero, $\mathrm{PS}=$ positive small, $\mathrm{PM}=$ positive medium and $\mathrm{PB}=$ positive big. The universe of discourse of the inputs was 
$-1,5$ and 1,5 , and outputs of the FLC were chosen between -3 and 3 with triangular membership functions, as shown in Figs. 6, 7 and 8. Tab. 1 shows the fuzzy rule base with 49 rules [20]. The FLC was modelled using the MATLAB fuzzy-logic toolbox GUI.

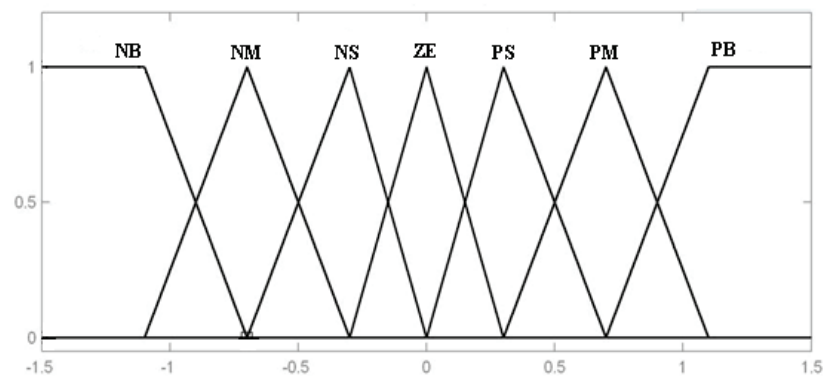

Figure 6 Membership functions of $e$

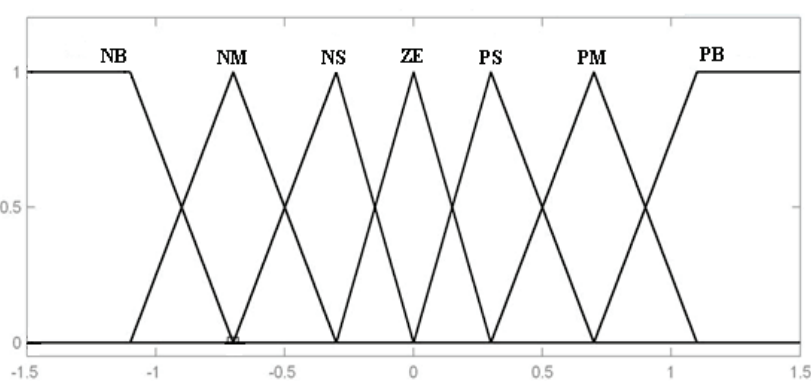

Figure 7 Membership functions of $d_{e}$

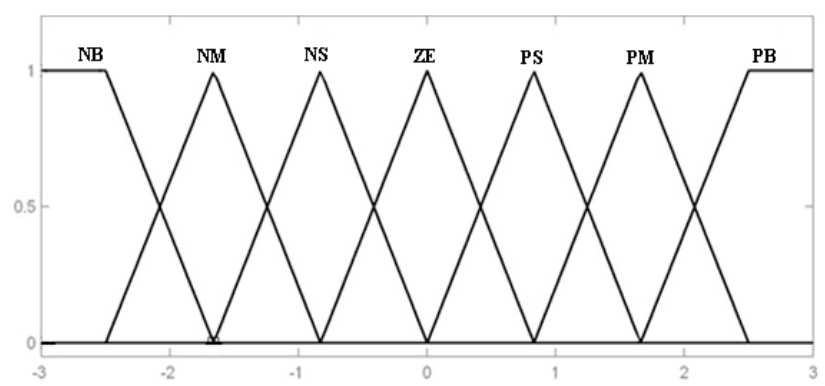

Figure 8 Membership functions of $d_{u}$

\begin{tabular}{|c|c|c|c|c|c|c|c|}
\hline$d_{e}^{e}$ & NB & NM & NS & ZE & PS & PM & PB \\
\hline NB & NB & NB & NM & NM & NS & NS & ZE \\
\hline NM & NB & NB & NM & NM & NS & ZE & PS \\
\hline NS & $\mathrm{NM}$ & $\mathrm{NM}$ & $\mathrm{NM}$ & NS & ZE & PS & PS \\
\hline $\mathrm{ZE}$ & $\mathrm{NM}$ & NM & NS & ZE & PS & $\mathrm{PM}$ & $\mathrm{PM}$ \\
\hline PS & NS & $\mathrm{NS}$ & ZE & PS & PM & $\mathrm{PM}$ & $\mathrm{PM}$ \\
\hline PM & $\mathrm{NS}$ & $\mathrm{ZE}$ & PS & $\mathrm{PM}$ & PM & PB & $\mathrm{PB}$ \\
\hline PB & ZE & PS & PS & PM & PM & PB & PB \\
\hline
\end{tabular}

\section{Simulation and discussions}

In this paper, three different types of speed controllers namely, PI, PID and FLC were used to investigate the dynamic behaviour of the PMSM drive.

The parameters of the PMSM used in the simulation research were as follows in Tab. 2.

Several simulation tests for vector control of the PMSM were carried out using the PI, PID and fuzzy logic controllers. The speed responses under different operating conditions such as step changes in the command speed or sudden changes in the load were observed. A performance comparison between the fuzzy logic controller and conventional PI and PID controllers was carried out by several simulations for confirming the superiority of the Fuzzy logic controller. Figs. 9a, 9b and 9c show the PI, PID and FLC response speeds in step no load. It is seen from Fig. 4 that the PI controller's rise time is less than the others, on the other hand the settling time of the FL controller is shorter than the others and the FL does not have overshoot at all. Hence, FLC performance is much better than the other two controllers.

Table 2 Parameters of PMSM

\begin{tabular}{|l|l|}
\hline Rated power $P_{\mathrm{N}}(\mathrm{kW})$ & 5 \\
\hline Rated voltage $U_{\mathrm{N}}(\mathrm{V})$ & 300 \\
\hline Magnetic pole pairs $p_{n}$ & 4 \\
\hline Rated speed $(\mathrm{r} / \mathrm{min})$ & 2300 \\
\hline Inertia $\left(\mathrm{kg} / \mathrm{m}^{2}\right)$ & 0,001469 \\
\hline Viscous damping coefficient $(\mathrm{Nm} \cdot \mathrm{s})$ & 0,0003035 \\
\hline Stator resistance $R_{\mathrm{s}}(\Omega)$ & 0,4578 \\
\hline Rotor flux linkage $\Psi_{\mathrm{f}}(\mathrm{Wb})$ & 0,171 \\
\hline
\end{tabular}

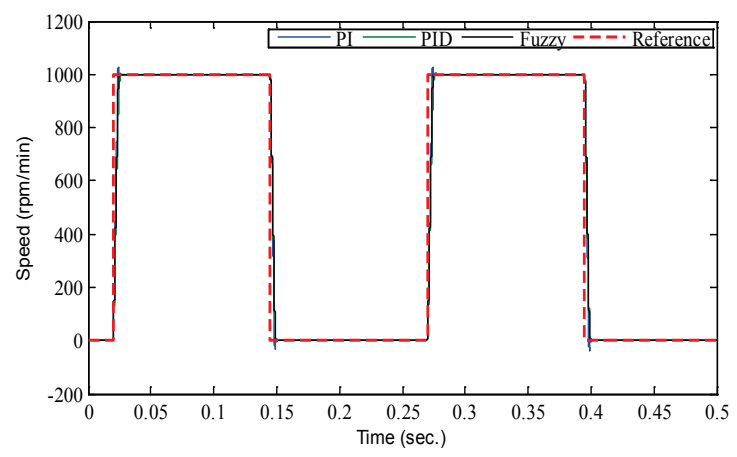

a)

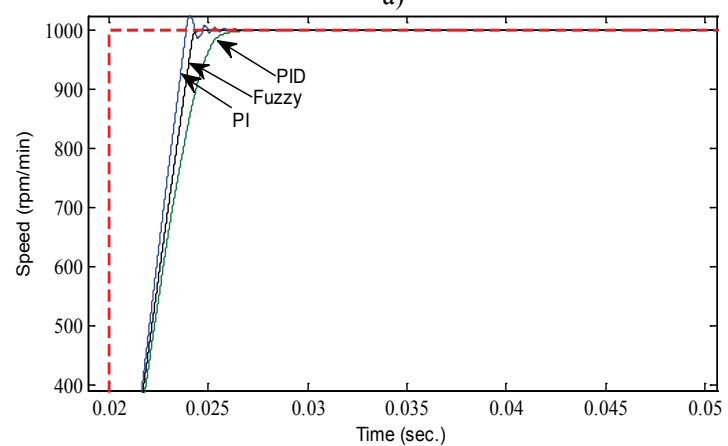

b)

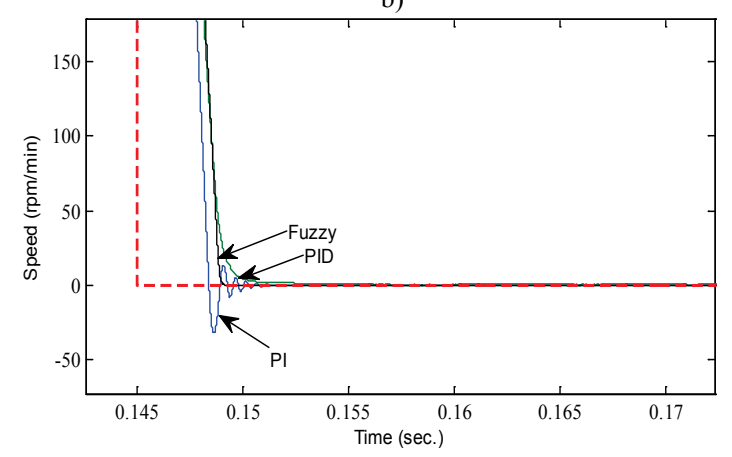

c)

Figure 9 Simulation results for speed in step: a) Reference and actual rotor speeds; b) zoom around $20 \mathrm{~ms}$; c) zoom around $150 \mathrm{~ms}$

Fig. 9 shows the speed tracking performance while changing the speed from $1000 \mathrm{rpm} / \mathrm{min}$. to $0 \mathrm{rpm} / \mathrm{min}$ at $0,15 \mathrm{~s}$ and again to previous state at $0,28 \mathrm{~s}$. It is evident from Figs. 9 and 10 that the FLC based PMSM drive 
follows the command speed without any overshoot and steady state error. The similar responses for full load condition are shown in Fig. 11. It can be seen from Fig. 12 that the FL drive can follow the command speed even after a change of armature resistance at different loading conditions.

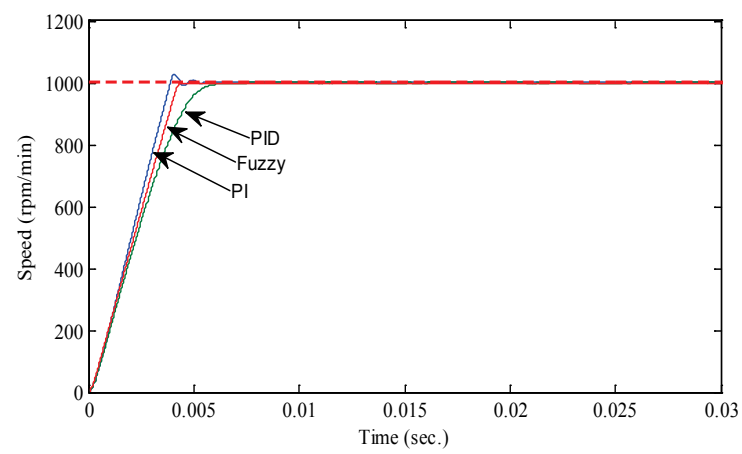

Figure 10 Starting responses of the drive using PI, PID and Fuzzy controller with no load

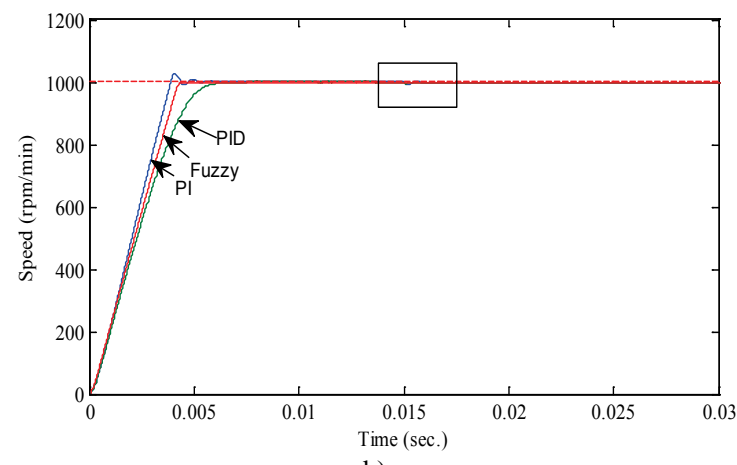

b)

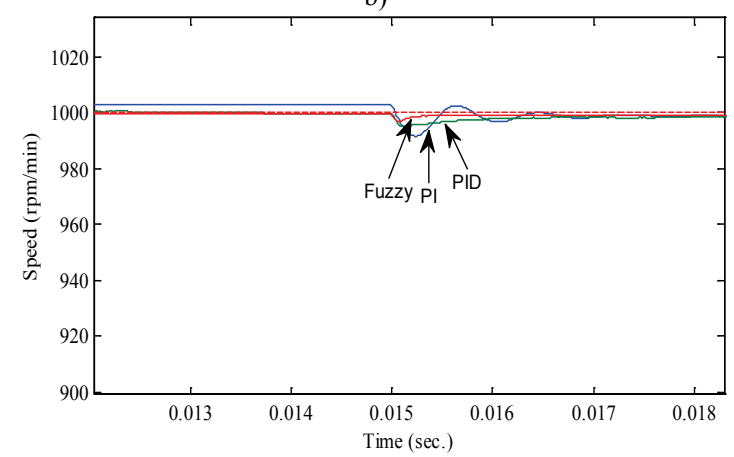

b)

Figure 11 b) Simulation results for speed under load torque at $0,015 \mathrm{~s}$; b) zoom around $15 \mathrm{~ms}$

The load disturbance has an effect on the speed responses produced by using both PI and PID controllers but the FLC has better transient response. It is evident from the results that the fuzzy controller gives better responses in terms of overshoot and fast response.

The FLC exhibited high performance in tracking the speed reference. The stator current, flux and torque responses of the PMSM with fuzzy controller were faster than the PI and PID controllers during the start-up and the step changes in torque. At the same time, dynamic behaviour of the PMSM with fuzzy logic controller was more stable than the PI and PID controllers.

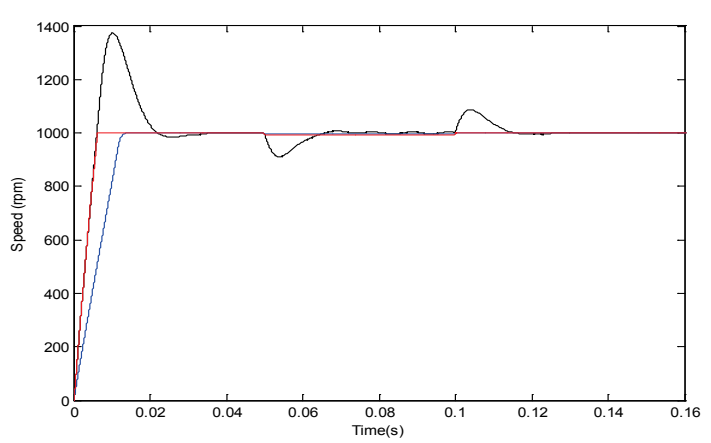

a)

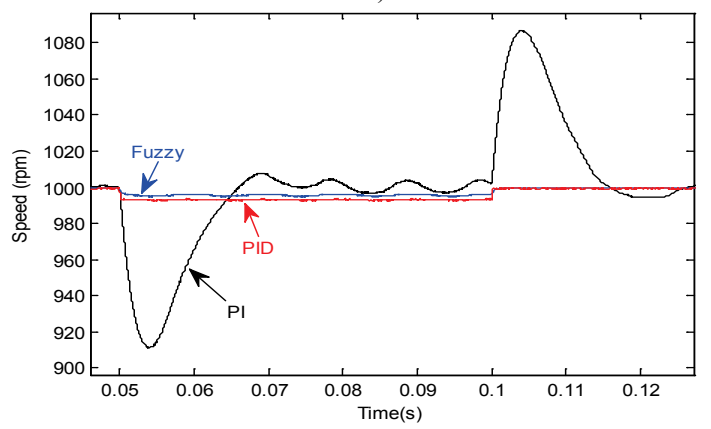

b)

Figure 12 a) Speed responses with change in stator resistance $R$ to $100 R$ at load and rated speed; b) zoom around $13 \mathrm{~ms}$

\section{References}

[1] Rahaman M. A.; Hoque M. A. On-line Adaptive Artificial Neural Network Based Vector Control of Permanent Magnet Synchronous Motor. // IEEE Trans. On Energy Conversion. 13, 4(1998), pp. 311-318. DOl: 10.1109/60.736315

[2] Song, L.; Peng, J. The Study of Fuzzy- PI Controller of Permanent Magnet Synchronous Motor. // Proceedings of the int. conference on Power Electronics and Motion Control, IPEMC'09, 2009, pp. 1863-1866.

[3] Guney, I.; Yuksel, O.; Serteller, F. Dynamic behaviour model of permanent magnet synchronous motor fed by PWM inverter and fuzzy logic controller for stator phase current, flux and torque control of PMSM. // Proceedings of the int. conference on International Electric Machines and Drive, 2001, pp. 479-485. DOI: 10.1109/iemdc.2001.939349

[4] Uddin, M. N.; Rahman M. A. Fuzzy logic based speed control of an IPM synchronous motor drive. // Journal of Advanced Computational Intelligence. 4, 2(2000), pp. 212219

[5] Singh, B.; Putta Swamy, C. L.; Singh, B. P.; Chandra, A.; Al-Haddad, K. Performance analysis of fuzzy logic controlled permanent magnet synchronous motor drive. // Proceedings of the int. conference on Proceedings of IEEEICON'1, 1995, pp. 399-405.

[6] Senjyu, T.; Kuwae, Y.; Urasaki, N.; Uezato, K. Accurate parameter measurement for high speed permanent magnet synchronous motors. // Proceedings of the int. conference on Power Electronics Specialists, 2001, pp. 772-777. DOI: 10.1109/pesc.2001.954212

[7] Feng, G.; Liu, Y. F.; Huang, L. P. A new robust algorithm to improve the dynamic performance on the speed control of induction motor drive. // IEEE Transactions on Power Electronics. 19, 6(2004), pp. 1614-1627. DOl: 10.1109/TPEL.2004.836619

[8] Mohamed, Y. R. Design and implementation of a robust current-control scheme for a PMSM vector drive with a simple adaptive disturbance observer. // IEEE Transactions on Industrial Electronics. 54, 4(2007), pp. 1981-1988. DOI: 10.1109/TIE.2007.895074 
[9] Fnaiech, M. A.; Betin, F.; Capolino, G. A.; Fnaiech, F. Fuzzy logic and sliding-mode controls applied to six-phase induction machine with open phases. // IEEE Transactions on Industrial Electronics. 57, 1(2010), pp. 354-364. DOI: 10.1109/TIE.2009.2034285

[10] Feng, Y.; Zheng, J.; Yu, X.; Truong, N. V. Hybrid terminal sliding-mode observer design method for a permanentmagnet synchronous motor control system. // IEEE Transactions on Industrial Electronics. 56, 9(2009), pp. 3424-3431. DOI: 10.1109/TIE.2009.2025290

[11] Foo, G. H. B.; Rahman, M. F. Direct torque control of an IPM-synchronous motor drive at very low speed using a sliding-mode stator flux observer. // IEEE Transactions on Power Electronics. 25, 4(2010) pp. 933-942. DOl: 10.1109/TPEL.2009.2036354

[12] Chiu, J. Y. C.; Ka-Sing Leung, K.; Chung, H. H. Highorder switching surface in boundary control of inverters. // IEEE Transactions on Power Electronics. 22, 5(2007), pp. 1753-1765. DOI: 10.1109/TPEL.2007.904209

[13] Choi, H. H.; Vu, N. T. T.; Jung, J. W. Digital implementation of an adaptive speed regulator for a PMSM. // IEEE Transactions on Power Electronics. 26, 1(2011) pp. 3-8. DOI: 10.1109/TPEL.2010.2055890

[14] Wai, R. J.; Chang, H. H. Backstepping wavelet neural network control for indirect field-oriented induction motor drive. // IEEE Transactions on Neural Networks. 15, 2(2004), pp. 367-382. DOI: 10.1109/TNN.2004.824411

[15] Zhi, D.; Xu, L.; Williams, B. W. Model-based predictive direct power control of doubly fed induction generators. // IEEE Transactions on Power Electronics. 25, 2(2010), pp. 341-351. DOI: 10.1109/TPEL.2009.2028139

[16] Chen, C. S. TSK-type self-organizing recurrent-neuralfuzzy control of linear microstepping motor drives. // IEEE Transactions on Power Electronics. 25, 9(2010), pp. 22532265. DOI: 10.1109/TPEL.2010.2046648

[17] Singh, M.; Chandra, A. Application of adaptive networkbased fuzzy inference system for sensor less control of PMSG-based wind turbine with nonlinear-loadcompensation capabilities. // IEEE Transactions on Power Electronics. 26, 1(2011), pp. 165-175. DOl: 10.1109/TPEL.2010.2054113

[18] Pillay, P.; Krishnan, R. Modeling of permanent magnet motor drives. // Proceedings of the int. conference on International Society for Optics and Photonics, 1987, pp. 289-293.

[19] Vas, P. Artificial-Intelligence-Based Electrical Machines and Drives-Application of Fuzzy, Neural, Fuzzy-Neural and Genetic Algorithm Based Techniques. New York: Oxford Univ. Press, 1999.

[20] Miloud, Y.; Draou, A. Fuzzy logic based rotor resistance estimator of an indirect vector controlled induction motor drive. // Proceedings of the int. conference on Industrial Electronics Society, 2002, pp. 961-966. DOI: 10.1109/iecon.2002.1185402

[21] Minz, R. B.; Thinga, R.; Tripathi, S. Adaptive fuzzy PID controller for speed control of PMSM drive system. // International Journal of Technical Research and Applications. 5, 2(2014), pp. 75-77.

[22] Lia, W.; Chena, Z.; Caob, W. Optimization of Permanent Magnet Synchronous Motor Vector Control System Based on Particle Swarm Optimization. // Journal of Information \& Computational Science. 11, 13(2014), pp. 4687-4696. DOI: 10.12733/jics20104498

[23] Kiruthika, G.; Minupriya, Ms. A. Vector control based PMSM drive using hybrid PI-FUZZY logic controller. // International Journal of Advanced Information Science and Technology. 23, 23(2014), pp. 113-117.

\section{Authors' addresses}

Mustafa Dursun

Duzce University, Technology Faculty,

Department of Electrical and Electronics Engineering, Konuralp Campus, 81620, Turkey

E-mail: mustafadursun@duzce.edu.tr

\section{Ali Fuat Boz}

Sakarya University, Technology Faculty, Department of Electrical and Electronics Engineering, Esentepe Campus 54187 Serdivan, Sakarya, Turkey E-mail: afboz@sakarya.edu.tr 